\begin{tabular}{|c|c|c|}
\hline \multirow{2}{*}{\multicolumn{2}{|c|}{$\begin{array}{ll}\text { DE } & \text { DE GRUYTER } \\
& \text { OPEN }\end{array}$}} & ECONOMIC THEMES (2018) 56(1): 1-15 \\
\hline & & DOI 10.2478/ethemes-2018-0001 \\
\hline
\end{tabular}

\title{
EXPLORING EDUCATION AND EDUCATION REFORMS FROM THE COMPLEX SYSTEMS POINT OF VIEW
}

\author{
Ljubinka Joksimović
}

University of Belgrade, Faculty of Economics, Republic of Serbia

$\bowtie$ joksimoviclj@gmail.com

Slavica Manić

University of Belgrade, Faculty of Economics, Republic of Serbia

$\bowtie$ slavica@ekof.bg.ac.rs

UDC

37.014.5

Review

paper

Received:

29.01.2018

Accepted:

17.03.2018

\begin{abstract}
The main motivation for this paper is that a negligible number of reforms in education systems, initiated all over the world, proved to be successful in terms of bringing desired results in promoting educational practice and its final goal - the promotion of students' learning and knowledge. Regarding the education system and its reform a change of paradigm has recently happened. In some cases, changes were made gradually, whereas in other cases it was completely abandonment of treating them as complicated systems with simple interventions and solutions toward the recognition and respect of their true complex nature. So, this reviewed paper explores new insights and tools derived from the theory of complexity. They can help to better understand and navigate the education system and its reform. Becoming familiarised with methodological implications of viewing the education system and its reform as complex system is recommendation for different stakeholders included in education system, such as teachers, students, researchers, administrators and policy makers. Advance awareness of both urgency and opportunities of analysing and respecting the education system as a complex system would contribute to better understanding the essence of dynamic wholeness of education and, for sure, would provide desired results of educational reform. For all of us that means more successful coping with the world characterised by a growing number of complex systems with growing intensity.
\end{abstract}

Keywords: education systems, reforms, complex systems, selforganization, managing

JEL classification: A2, I2 


\section{Introductory considerations}

In Serbia desperate parents, confused children and disgruntled employers have been observing ministries for years for bother with reform of education. One minister begins, next fixes or adds to some of good experiences in reform from other countries. Numerous educational reforms were attempted, but they all had in common a mutual lack of patience, quality and professional orientation that teachers need in order to achieve desired results of the reform. It often happened that the same reforms were trying to push, by only putting another fancy title, without any sort of analysis of their previous epitomes. The result of this confusion is that reforms that have begun at all levels of education system are deformed, that we no longer remember the initial state, nor why they started.

It is not for consolation that in many developed Western countries can be found that schools have a long history of routine and confusing changes in education. In the last two decades, it is not unusual, that if you asked any participant in educational system about reform of school system regardless whether he is a school principal, teacher, administrative worker or any other participant, they would all shout out the same phrase: "Frustrating!". Very few initiatives, all of which took much time, brought desired results in promoting educational practice and its final goal - the promotion of students' learning and knowledge.

Often discussing diversity or variability of the outcomes of the same educational reform in different schools and districts has one logical explanation. The fact about the variability, that was taken for granted for a long time, was interpreted as consequence of an unwillingness or reluctance of some actors of school to follow the directives (Ravitch, 2010; Trombly, 2014). This proved to be naïve. The true reason for this are contextual differences in which the reform is being implemented. The reform that has been successful in one school does not mean an automatic success in another school. Elmor (2004) has pointed out that the reform applied in one school or district doesn't need to bring the instant result in another school or district: "Improvement is a developmental process, not an act of compliance with a policy. Schools 'get better' by engaging collectively in the acquisition of new knowledge and skills, not by figuring out what policy makers want and doing it" (p. 227).

From all the above mentioned, it is evident that without a true support of rationality behind every implementation and giving enough opportunities to a reform to "take root", the results cannot be expected. The support to reforms from teachers is not a question of pragmatism or politics. Teachers have to be active participants in analysing their own practice, student progress and standards of student learning. Information sharing is no less important, as well as cooperativity, building trust and a high level of advocacy along with persistent and coordinated efforts of teachers in implementations of the reforms. 
In order to achieve all that, it is crucial to provide enough material and human resources, as well as give enough opportunities to all participants in educational reform. Some of the obstacles are represented in inflexible metrics, preferred by policy makers, since it provides them much desired accountability. It happened that policymakers proposed some kind of reform based on its political support only, with little regard to its academicals weight or compatibility with existing and current initiatives (Elmor, 2010). This suggests two connected things. First, change cannot occur from above, even if it is formulated well, but it has to come from bottom, by those who conduct process of education. In world characterised by new technologies and instant feedback, elections at multi levels lead to short - termism, when researches have already documented that without giving enough opportunities to reform to 'take root', results cannot be expected. The strongest effects are seen 8 to 14 years after reform begun (OECD, 2016). Second, almost all the above discussed suggests that successful navigating of educational system and its reforms need to take care of their complex nature.

If we want to come out from vicious circle in education, then we must recognise that our world is full of complex causality; event with multiple contributing causes, conflict on different levels and scales (personal, social, national and international), social media challenges and chaotic oscillations in weather, the stock market and ecology. Understanding complex systems is fundamental to navigating the contemporary knowledge education and its reform. But, also the education system itself has key characteristics of complex system; it consists of many actors which organise themselves and interact with each other in many different ways, creating new properties, structures and behaviors.

The second part of the paper is deals with relatively recent made differentiation among simple, complicated and complex systems. In third part, it is explored the key concepts of modern theory of complexity and new insights derived from it for education. Last part of the paper presents some of the ways to make complexity systems more understandable and manageable.

\section{Three types of systems: simple, complicated and complex system}

After great team-work on developing methods and scientific researches that address complexity by Santa Fe Institute from the mid - 1980 there were new breakthroughs, in particular, in differentiation of systems in human science. The differentiation in simple, complicated and complex systems offered by Glouberman and Zimmerman (2004) has become very influential.

Simple problems individuals address daily, often informed by habits, post experience, routines and protocols. Simple systems or problems have relatively clear definitions. It is possible that problem is seen as a difference between what is and what should be. Usually experts from field where problem is noticed establish 
a protocol or provide recipe as a kind of guide to choosing a solution. Experts have the ability to test potential solutions using tools from their technical and scientific fields, until reach the correct answer, i.e. solution. So, problem can be clearly evaluated, the solution has an end-point. Problem can repeat many times, but already applied standard methods provide predicative results. Snowden and Boone (2007) maintain in their Cynefin Framework that in simple context cause equals effect and we are in sphere of known. Since there is no debate concerning the level from which is intervened, policy makers have simple task. It is down to delegate the set of procedures to be followed (Fig. 1).

\section{Figure 1. The Cynefin knowledge framework}

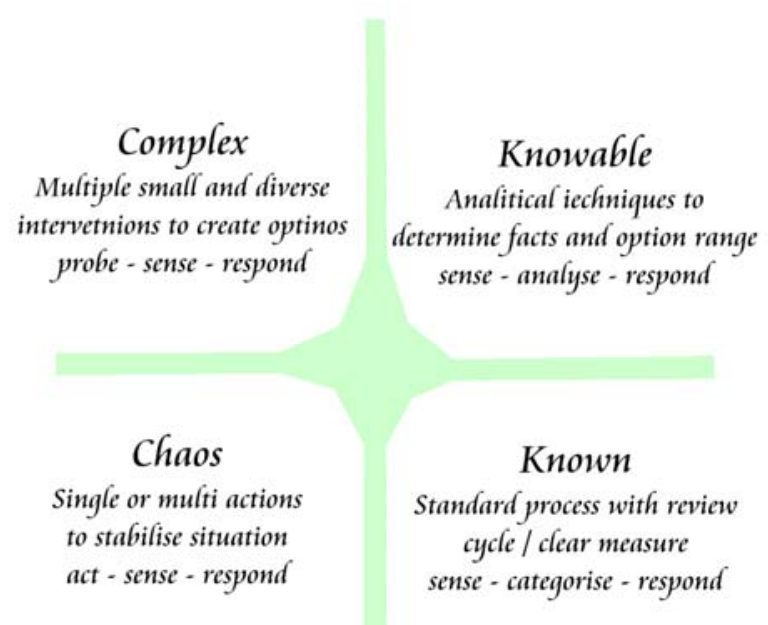

Source: Snowden, D., and Boone, E. (2007)

With complicated problems, protocols or recipes are not helpful. High level of expertise have to be engaged which through combination and coordination of knowledge from different science fields enable to reach to resolving the problem on satisfactory way. Mainly, because complicated problems have similar initial conditions or context, once obtained satisfactory result can be repeated with similar other problems with high degree of reliability. Experts' data analysis in these systems cannot find clear link between cause and effect. In that context, policy makers need more time and patience in encouraging different opinions and then to undertake agreed intervention which should provide workable and replicable solution. Examples of complicated system are an automobile or sending the rocket to the Moon.

Complex systems are always in evolution and so, they cannot be predictable. They are intractable and difficult to define. There are many perceptions and conflicting values and interests by different social and political actors. These values and interests are usually subjected to changes in striving to reach solution. It is 
impossible to establish a set of criteria to assess whether solutions are good or wrong. Complex systems are based on interconnections, emergence of new phenomena and self-organisation (it will be said more about these characteristics later, when the essence of complex theory will be considered). Because every problem can be interpreted as a symptom of another problem, it is impossible to find true cause. There is no solution in terms of definite answers. In this context, policy makers may try on creating some safe space for structures, patterns to emerge by relying on multiple feedback analyses of judgments of a large number of stakeholders, so increasing communication with such system to its the highest level. Such solutions are likely to be provisional and incomplete in various degrees. As examples of complex systems often are quote: raising a child or an ensemble of car travelling down a highway (Alford, J. and Brian, H. 2017)

But, also almost every day we hear about new phenomena in global warning, drug abuse, child protection, natural disasters, migration, poverty, security and so on. The great ignorance of these complex problems could be also explained by their increasing in number and intensity.

What is important to notice is that just recently a change in paradigm of researchers' thinking happened regarding to the education system and its reform: in some cases, gradually and in other cases completely abandonment of treating them as complicated systems with simple interventions and solutions to recognition and respect their true complex nature.

\section{The theory of complexity and new insights derived for education}

Complexity theory posits that systems begin as collections of element or actors which organise themselves and interact with each other in many different ways. A central point of complexity theory are relationships or interactions among constituent elements or actors in dynamic environment or systems. These interactions spontaneously produce that new (and to some extent unexpected) properties and behaviors emerge in systems or environment which are not visible from its elements in isolation. The essence is reflected in the fact that the whole becomes in real sense more than the sum of its constituent elements. The new patterns or structures are developed and old ones changed. Creating new patterns and new entities prevents prediction, because measurement is only possible when we know a good deal what we are talking about. Closely linked with this is notion of self-organisation which is defined as the way in which interactions among elements or actors of system lead to self-sustain structures or patterns. Only by these two qualities, school and education system can be classified as complex. Schools and their systems are self-organized in that their structures and functions often spontaneously shift as actions and reactions of autonomous agents become interlinked creating positive and negative feedbacks. They are also emergent in that, as entities, their continual evolution transcends the sum of constituent parts. 
In the theory of complexity, notions as a path dependence, inertial momentum, lock-in and tipping points are closely associated with the above mentioned, but for sure, expand and enrich the ideas of continuity and change. These notions together point out what other conditions are needed for the emergence of positive and sustainable changes and development in education systems.

The notion of path-dependence is seen from the fact that school is structuredetermined as it adapts to changes within social, economic and political context, while internalises learning and evolving from systemic memory inherent in the system. Also, the notion of path-dependence suggests that inertial momentum of particular phenomenon will continue to move phenomenon along the same existing path as long as a sufficient inertial momentum of competing phenomenon does not lead to change in path. Dimension of power of competing phenomenon causing shift depends on degree of difference in strength and direction between existing and emerging power structure.

Van Twist et al. (2013) research on coping with very weak primary schools in the Dutch education system, suggested that policy interventions in context of weak schools did not show evidence of linear pattern. Feedback loops interventions have effects, but these effects cause new dynamics, new effects, and so on and so forth. Dutch approach has shown at the end as effective, but remained unclear what effect or set of interventions is responsible for success. This is a common finding in complex systems. Indirect consequences - second or third order - are often more important than the first order direct consequences and can be are stronger.

One of the most illustrative examples of notion of lock-in is the dominance of the QWERTY typewriter key-board, for almost century. It was adopted and mass produced by Remington, and even there was inefficient large number of typist and companies adopted the same and learn on it. Until computer keyboard is launched the offer of more efficient keyboard layouts had a small chance to break locked-in monopoly of the QWERTY keyboard (Mason 2014).

In a complex system, it is not uncommon for small changes to have big effects and for effects to come from unanticipated causes. These effects or events usually named tipping points may cause tremendous changes across the system via cascading effects. Usually, these effects are compared with earthquakes, because it is difficult anticipate and stopping them is futile. Returning the education system, this may be translated that for policy makers would be illusionary to prevent them. Rather, their task would be to recognize their occurrence and engage to limit unintended consequences.

If there is a sincere wish that our students grasp how complex systems work and to build the habit of systems thinkers, it is needed to change the key ways in which we introduce them to new knowledge. Usual teaching approaches mostly come down to break complex systems into separated parts, so they are easier to understand. These learning strategies without is ever being a learning goal means 
that students for resolving problems have a reductionism as a key methodology. More cautious analysis of curriculums has, also, showed their reductionist aspect, i.e. breaking knowledge up into subject's silos that usually remain unconnected from each other. Also, it can be noticed the tendency to look linear cause - and effect relationships between these separate parts and that in turn creates a problem because it revokes the essence of the dynamic whole that makes system what it is. With emergence of theory of complexity, we have to help students to understand the wholeness while still making parts accessible, to develop new habits of mind and adopt of practice in more contingent thinking. Contemporary usual educational practices have to be re-evaluated, creating chances to reconnect the natural, the social science and the arts (OECD, 2016).

\section{Ways to make complex systems more understandable and manageable}

\subsection{Simplex systems}

Some authors like Van Geert and Steenbeek (2014) and some others explain that it is important to simplify complex systems, like education, so the agents can understand them. In scientific theory, simplex systems are created through practice that comes out from participation in the complex system. Agents who participate in complex systems have different kinds of simplex systems, in order to understand their role and practice at their jobs, which translates into functions and goals they want to achieve. In terms of education, agents represent educators, researchers and policy makers, who through their interactions that includes conflicts and incompatibilities between their personal simplex systems, we can observe complex system. Focusing on the basic simplex system properties of educational researchers, including causality and also variability as the source of knowledge, it is making effort to contribute to understanding of the hidden links between simplex systems that participate in the complex system of education.

Education possesses a significant number of actors and features that interact in different ways, making teaching-learning process difficult or easing it. Previously mentioned simplex systems which come from complex systems are aiming to change such complex system. In the field of education, the change can come from the teacher's professionalisation, better habits of students and reforms of school's curriculums or school's reform as a whole, etc. From the angle of educational researchers and policy makers as agents in the educational system, there are two types of variability in the educational data complex systems. These are intra- and inter-individual variabilities, and the choice of one of them consequently affects the type of result that the research or reform produces.

Education is a complex system because it is formed by many parts of levels of organisation and interactions among their participants, children, students and 
teachers, and it reaches to policy makers, and also to educational reform as a whole of such complex system. The interactions among these participants can be either short term, like the interactions between student and professor during the class, or long term, like in the educational reform which stages can be prolonged to couple of years. The interaction raises the question about what people do when they are being taught or they teach other people, how that process affects their surrounding that they organize with the aim to educate, and what tools are used to make education possible. Such extremely complex system, in order to be understandable and manageable to its participants, as we emphasized earlier, has to be simplified so that individual goals or concerns could be determined.

It has to be emphasised that the dynamics of the complex system serves as an important tool to arrive to simplex system, i.e. clear and dynamical understanding of the complex system and it also gives necessary building blocks for models and theories of educational process as well as different kinds of educational practices.

The cognitive control of understanding, emotional control of giving value to the things and phenomena and controls in manipulating and dealing with practical issues are the forms of control in simplex systems. Having control means to understand how all elements interact with each other, how to evaluate the same elements and how to modify them in order to achieve complex concerns and goals. Teacher wants to understand how he/she influences the student in relationship to what he teaches. This understanding can take many different forms: the narrative form with the student, the grade, or giving evaluation at teacher-parent meeting. Such practical assessments are being correlated with specific values: what represents good education, what we expect from girls and boys, how students should behave in class, etc. The assessments are implicit and situational, and their value can be observed only in the context of the function they perform. Assessments concerning understanding, assigning value and accomplishment as various forms of control, in general sense, are linking with the concept of agenti, i.e. dynamics of agent system which form modeling with aim of understanding complexity of agent system.

Agent systems form the fundamental concept for understanding all theories of human behaviour and actions. Agent (student, teacher, policy maker and parent) acts with the intention of carrying out his concerns and goals. The listed concerns range from simple, like psychological agent's needs, to specific, like psychosocial and educational goals, e. g. the teacher's objective to teach a child to read. Agents constantly estimate how their actions lead to fulfilling their goals in the process we call appraisal, and they represent the distance between their concerns and realisation of their goals. What we intend to explain, was that the components of simplex system, like pedagogical approach, maintained practices and beliefs interacts with each other leading to self-organisation in dynamical systems, like self-sustained ideas, practices and motivations, which are built in complex systems. 


\subsection{Lessons from ecology}

In recent times it is suggested that lessons from ecology science can provide good ideas how complex system can be more manageable (Berlow, 2010).

Berlow in his research on interactions of aquatic species relied on visual modeling to comprehend the whole compound picture. Model was built from simple nodes connected on wireframe, similar to model of molecules which can be seen in classroom. He found that in case of following only on the interactions of any two species much important information was lost. After a lengthy experiment he noticed that some nodes were separated in terms of that they had different sphere of influence. Also, they could cause changes and self-sustained fluctuations in a sense of waves coming from small triggers, what manifested as in case of tipping points. He concluded that this insight could lead to improve policy design and also provide indications to approach education system in more manageable way. Further, this means that reform in educations need not necessary assume sweeping by big broom, or rejection of large number elements from the system. It is suggested to use targeted application in sense of putting concentration on right nodes that provoke positive fluctuations or waves which after certain time produce desirable positive and to some extent a certain result. The message would be that the task of policy makers could be reduced to create conducive space and triggering event that would spreading to the system (Snyder 2013).

Figure 2. Influential nodes which can make system more manageable

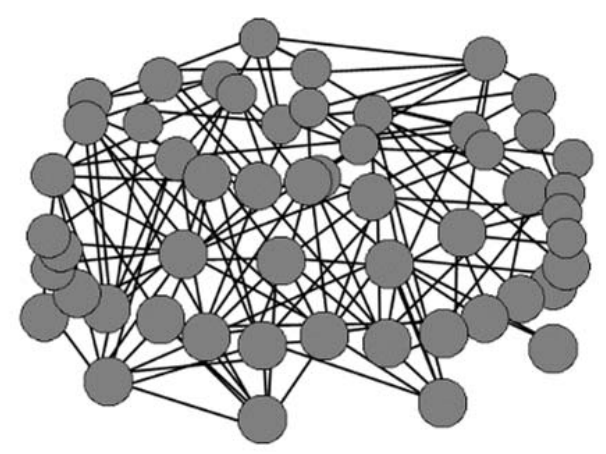

Source: Authors

As the confirmation of the valid lessons from ecology we found that the cases concerning to the reform strategies in Ontario and Hong Kong are the most frequently mentioned and scrutinised.

At first, the city of Ontario was successful in reform because it concentrated on only three goals: literacy, numeracy and high school graduation. In order to introduce with goals and processes all stakeholders (ministers, provincial officers, teachers, principals, parents and community groups), government gathered them in different 
cooperation forms. Feedback mechanism creates by the actors allow them to design their own reform process. Approach was neither top-down nor bottom-up, but the results have been impressive (Mourshed, et.al. 2010, Fullan and Levine 2009).

Key nodes were capacity building and professional development. Capacity building involves raising the collective effectiveness of a group through development individual and collective knowledge, competencies, resources and motivation (Fullan 2006). The Government Ontario was committed to: (1) hire thousand new teachers; (2) reduce class sizes;(3) prioritize preparation and professional development time; (4) create partnership with universities; (5) make educational agreement with employers which would lead to creating new needed skills, improved learning and, consequently, to higher employment and (6) increase internal and external accountability.

Also, a large number of researchers of education reforms around the world apprise that Hong Kong had one of the most successful implementation of whole education system reform. The reform involved government officials, academics, teachers and administrators, over 10,000 people, in 20-month long process at seminars and forums. Similar as in Ontario the reform strategy, iterative feedbacks were considered as a key element of Hong Kong's reform. Mechanism of these feedbacks discovered that the main insufficiencies are reflected in following: (1) learning was mainly reproductive, influenced by nature of exam, without deeper thinking, exploration and creativity; (2) relationship between teacher and pupil was one-way passive process.

In order to make educational shift in direction of strong critical thinking, more innovative skills and knowledge, two key nodes were highlighted. First node relates to abandonment of passive knowledge transmission toward active students' involvement. This is further implied inclusion of moral and civic education, learning outside of classroom, learning based on project and IT. Second node is related to insisting on formative approach instead of summary testing, what also means avoiding simple reproduction of knowledge from text books.

In accordance with complexity approach, for implementation of program pretty long term is determined, more than 15 years. It was considered that this time span could reduce reform fatigue. At the same time, it would and does work in direction of creation sustainable stability of education system (Lee and Gopinathan, 2014).

\subsection{Agent - based modeling (ABM)}

Agent-based modeling belongs to a class of computational model for simulating the actions and interactions of different agents (individual, household or organization) in order to assess their effects on the whole system. His/her power is reflected in providing additional, important insights which otherwise cannot be recognized from quantitative and qualitative approaches in educational research. 
In some countries there are two systems of attending school. First system is catchment area system, where by regulation, students are obliged to attend schools that are geographically close to their residence. On the opposite side, there are choice-based systems where households have more freedom and control over choosing schools for their children. Many controversies have emerged after proposed transition from one to other system. The proponents of the choice-based system claim that it provides better access and better education for those who are part of lower income population, as well as the support needed for educational reform. On the opposite, the proponents of the first option, claim that choice-based system will not bring the improvement in schools, but it will only lead to the drainage of resources from schools with lower achievements, and worsening their state.

In order to simulate the transition, the agent based model was used. The agents in the model are schools and students. The schools are differed in capacity and quality, while newly opened schools imitate the schools with best performances. Students differ in their household backgrounds and abilities. Ranking of schools by students is obtained using preferential function based on the mean achievement and geographical proximity of the school. On the other side, the students' achievements are the result of the combination of individual traits and parameters of added value (amount that student achievement increases each year) of school they attend. What follows, is observation of model, of mentioned transition, through the example of Chicago public schools (Maroulis.et.al. ,2014).

The important part of model represents entrance of new schools in the system, as well as quality and quantity of these schools. Thorough analysis of the model has showed very strange non-compliance between results at micro and macro level, as well as fact that choosing the school of better ranking, by the household, did not bring better achievement at district level. Since the only way to accomplish better achievements, from perspectives of schools, in the whole system, is based on imitation of the best schools by new schools, the schools that enter later have fewer opportunities to apply the same mechanism.

Earlier empirical research of choice-based system has gone in two directions. One direction of the research, where observed students attended schools of their choice, led to controversial findings. Another path of the research that was focused on achievements of the students who passed the lottery that had the goal to solve the problem of the overcrowding schools of choice, did not lead to any definite results.

It has to be emphasised that the analytical problem of relationship between attending the school of choice and academy achievement, aside from the obvious evaluation problems, has even bigger issue because such analysis does not take into consideration the system's effect of different curriculums between the schools. The progress in achievements can come from many other mechanisms that go beyond the simple school choice of the student, especially if it is observed through the 
competition between schools and new investments in existing schools. The dynamical system, which introduces reform following flows occurred: more choice leads to greater movement of students. Schools that lose students experience the pressure to carry out changes in order to keep the existing students and attract the new ones. The possibility of choosing for students leads to the entry of new schools into system which, in turn, enhances the pressure in schools through increased level of competition. In such system, if the movement of the students does not lead to clustering of students with low achievements, the mean value of district student achievement will be higher than before.

The model also demonstrated that entrance of the newest schools, the ones that have less space to imitate best schools, depends on combination of factors: the contributions of students who participate in chosen program, the importance of school achievements for a household, assumptions that households make about the quality of new schools, how quickly old schools close and the tempo of new schools trying to enter a system. However, the most interesting result of agentbased modeling represents puzzling incompatibility between student-level and district-level behaviour, that is reflected in the fact that: the more students emphasise school achievements over the geographical proximity, the mean value of district achievements becomes lower.

These results of the Chicago public school model suggest that district strategy should aim to more even spread out closing of old schools and opening of new schools over time. It turned out that the biggest drawback of model was a noninclusion of possibilities of internal school improvement as the response to pressure by the competition, namely from new schools. Also, to better calibrate the model, better understanding of the student's preferences is necessary, as well as better correlation between the student's choosing of a school and characteristics of households from which they originate, i.e. socioeconomic status and existing students' achievements.

\section{Conclusion}

Despite many attempts to reform the educational systems in terms of promoting educational practice and its final goals - the promotion students' learning and knowledge, little changes have been achieved in the last two decades. In large part, this is attributed to inappropriate assumptions about the nature and origin of order in education systems. Teaching approach mostly come down to break lecturing material into separated parts, so it is easier to understand. Students have been thought reductionism as a key methodology for resolving problems. In curriculums, knowledge is breaking into subjects' silos that usually remain unconnected from each other. Tendency to look linear cause-and-effect relationships between these separate parts, in turn, creates problem of non-understanding the wholeness of problem that is thought. Policymakers propose reforms mainly based on political 
support with dominant short-termism, which does not allow enough opportunities for reform to take root.

Not long ago, in a growing number of cases, it was noted that education and its reform were recognised, treated and respected as a truly complex system. Insights from theory of complexity documented that schools and education systems meet main criteria necessary for phenomenon to be classified as complex systems. Schools and education systems are self-organised in their structure and function, and often spontaneously change as the actions and reactions of autonomous agents become interconnected. They are also emergent, in terms that as entities their continual evolution transcends the sum of component parts. Also they show phenomena as path-dependence, lock-in and tipping points. Last phenomenon points that sometimes small changes in education system may have big effects, introducing a great amount of unpredictability in behaviour of system.

As ways or tools to make complex systems more understandable and manageable the authors analysed simplex systems, lessons from ecology and agentbased modeling. Simplex systems are created through practice that comes out from participation in complex systems. Teacher wants to understand how he influences the student in relationships to what he teaches. Simplex systems as a tool for understanding complex systems, suggests that practical assessments such as grade or giving evaluation at teach-parent meeting are being correlated with specific values: what represents good education, what we expect from girls and boys, how students should behave in class, etc.

Lessons from ecology suggest us to concentrate on specific nodes of great influences instead of following all interactions between elements. It can be translated into message for education reform in terms that reform need not necessary assume sweeping by big broom. Many times it is more helpful to use right nodes that provoke positive fluctuations of waves which after certain time produce desirable positive and to some extent certain result. Successful reform strategies in Hong Kong and Ontario were been relying on this valuable insight from ecology.

The main lessons, from the presented agent-based model have reflected in fact that better achievements from individual schools do not translate to better achievements on a district level. This is true, because when looking from a perspective of a district achievements (complex system), it is not a matter of simple addition of individual achievements from single schools.

Can this new view from complexity theory and new suggested tools help us to better understand why change in education is difficult, unpredictable and does not tolerate short-termism? If the answers are provisional "yes", then it is urgent to foster a broader awareness of intellectual and methodological advantages of this approach to policy makers and other stakeholders who shape the educational policy. 


\section{References}

Alford, J. and Brian, H. (2017). Wicked and less wicked problem: A typology and a contigency framework. Policy and Society, 36 (3), pp.397-413.

Berlow, E. (2010). How complexity leads to simplificity. TED Talks. Retrieved from: www.ted.com./talks/eric_berlow_how_compliexity_leads_to_simplificity.html.

Elmor, R. (2004). School reform from inside out: Policy, practice and performance. Cambridge, MA; Harvard Education Press.

Elmor, R. (2010). Used to think...and now I think...Reflection on the work of school reform. Harvard Education Letter, 26 (1), pp. 7-8.

Fullan, M. (2009). Large scale reform comes of age. Journal of Education of change, 10 (2), pp. 101-113.

Fullan, M. and Levine, B. (2009). The fundamentals of the whole system reform: A case study from Canada.. Education Week, 28 (3), pp.30-31.

Geert, A. and Steenbeek, H. (2014). The good, the bad and the ugly: The dynamic interplay between complicity, educational practice, policy and research. Journal of Complexity in Education, No.2, pp.22-39.

Glouberman, S. and Zimmerman, B. (2004). Complicated and complex systems. In Marchildon, P. and McIntosh, M. (Eds.). Romanov Papers: Changing Health Care in Canada. University of Toronto Press.

Lee, M. and Gopinathan, R. (2017). Globalisation and education reform in Hong and Singapore. International Handbook of Education and Policy Research, Springer International Publishing AG.

Levine, J. and Jacobson, M. (2017). Education as complex system:Implication for educational researchs and policy. Retrieved from

https://www.researchgate.net/figure/312938036

Maroulis, S. et al. (2014). Modeling the transition of public school choice. Journal of Artifical and Social Simulation. 17 (2), pp.23-32.

Mason, M. (2014). Complexity theory in education governance: Initiating and sustaining change in Understanding complexity: The future of educational governance, UNESCO, International Bureau of Education.

Mourshed, M. et al. (2010). How world must improve school system keep getting better. Retrieved from McKinsey@Co.McKinseyonsociety.com/final.pdf.

OECD (2016). Governing education in complex world. OECD Publishing Paris.

Ravitch, D. (2010). The death and life of the great American school system: How testing and choice are undermining education. New York, Basic Book.

Snowden, D. and Boone, E. (2007). Lider's framework for decision making. Harvard Business Review, 85 (11), pp. 68-70.

Snyder, S. (2013). The simple, the complicated and the complex: Education reform throuth the lens of the complexity theory. OECD Education Working Paper, no. 26.

Tromly, Ch. (2014). School and complexity. An International Journal of Complexity and Education. No.2, pp.40-58.

Van Twist, M. et.al. (2013) Coping with very weak primary schools:Towarcs smart intervention in Duch education policy, OECD, Publishing, Paris 


\title{
ISTRAŽIVANJE OBRAZOVANJA I OBRAZOVNIH REFORMI SA STANOVIŠTA KOMPLEKSNIH SISTEMA
}

\begin{abstract}
Apstrakt: Glavna motivacija za ovaj rad se ogleda u činjenici da se zanemarljiv broj reformi u obrazovnim sistemima, iniciranih širom sveta, pokazao kao uspešan u smislu dolaženja do željenih rezultata u unapređenju obrazovne prakse i njenom krajnjem cilju - unapređenju učenja i znanja studenata. Nedavno je došlo do promene $u$ paradigmi promišljanja kod istraživača obrazovnog sistema i reforme: u nekim slučajevima dešava se delimično, a u drugim slučajevima potpuno napuštanje njihovog tretiranja kao komplikovanih sistema sa jednostavnim intervencijama i rešenjima i okretanje prema prepoznavanju i poštovanju njihove istinske kompleksne prirode. Dakle, ovaj pregledni rad istražuje nova saznanja i instrumente koji proističu iz teorije kompleksnosti, a koji mogu pomoći da se bolje razume i upravlja obrazovnim sistemom i njegovim reformama. Upoznavanje sa metodološkim implikacijama tretiranja obrazovnog sistema i njegovih reformi kao složenog sistema je preporuka za sve učesnike u obrazovnom sistemu, kao što su: nastavnici, studenti, istraživači, administratori i kreatori politike. Povećana svesnost, kao i prepoznavanje što kraćeg vremenskog roka za analiziranje i uvažavanje obrazovnog sistema kao kompleksnog sistema bi doprinela da se bolje razume suština dinamičke celine obrazovanja kao takvog i sigurno bi dala željene rezultate $u$ reformi istog. Za sve nas ovo znači uspešnije suočavanje sa realnošću koju obeležava rastući broj kompleksnih sistema, sa rastućim intenzitetom.
\end{abstract}

Ključne reči: obrazovni sistemi, reforme, kompleksni sistemi, samoorganizacija, upravljanje

\section{Authors' biographies}

Ljubinka Joksimović has been employed at the Faculty of Economics, University of Belgrade, since 1976. She was appointed as a Full Professor in 1997. Her main fields of interest and research are the following: comparative economic systems, economics of the European Union, social capital and economics of public sector. She teaches courses at the undergraduate level: Comparative Economic Systems, Economics of the EU, Economics of Transition. Also teaches Master and $\mathrm{PhD}$ courses. She is a member of the Scientific Society of Economists in Serbia and Belgrade Association of Economists.

Slavica Manić has been employed at the Faculty of Economics, University of Belgrade since 1989. She was appointed as an Associate Professor in 2012 and 2017. Her main fields of interest and research are the following economic methodology, philosophy of economics and economics of education. She teaches courses at the undergraduate level: Method of Economic Analysis, Economics of Transition. Also, she teaches at the Master courses level. She is a member of the Scientific Society of Economists in Serbia. 